広範な門脈内ガス血症を呈した上腸間膜動脈塞栓症の 1 例

\author{
苫小牧市立総合病院外科
}

渡辺正明高橋周作広瀬邦弘佐治裕

症例は認知症のため他院に入院中であった85歳, 女性. 2004年 6 月21日腹痛が出現. 腹部 X 線写真で腸閉塞の所見を認めた. 23日下血が認められたため, 精査加療目的に当 院外科に紹介された。身体所見では腹部は膨隆し，著明な腹膜刺激症状を認めた．腹部 CT 検査で, 門脈内のガス像を認め, 腹水を認めた. 汎発性腹膜炎の診断で, 発症からお よそ53時間後に緊急手術を施行した. 開腹所見では Treitz 勒带から結腸脾燓曲までの広 範囲の腸管壊死を認め, 門脈内ガス血症を伴う上腸間膜動脈閉塞症であった. 小腸全切 除術, 拡大結腸右半切除術, 空腸瘦造設術を施行した。術後経過は良好で, 術後20日で 他院に軽快転院した.門脈内ガス血症を伴う上腸間膜動脈閉塞症は救命率が非常に低く， 予後不良である．われわれの検索しえた限り本邦ての救命例は，本症例を含め 9 例の報 告のみである. 文献的考察を加え報告する。

索引用語：門脈内ガス血症, 上腸間膜動脈閉塞症, 短腸症候群

\section{緒 言}

門脈内ガス血症を伴う上腸間膜動脈閉塞症は救命率 が非常に低く，予後は不良であるが，積極的治療によ り救命しえた症例を経験した. 文献的考察を加え報告 する.

\section{症例}

症例：85歳, 女性.

主訴：腹痛.

既往歴：70歳から高血圧, 高脂血症, 糖尿病に対し て内服治療をされている。心疾患の既往なし，77歳： 脳梗塞.

現病歴：2004年 6 月 21 日:認知症のため他院に入院 中であった。同日午前に腹痛が出現した。腹部 X 線写 真から腸閉塞と診断された. 23日：下血が出現したた め, 当院外科に精查加療目的に紹介. 腹部 CT で門脈 内ガス血症を認め, 身体所見から㲸発性腹膜炎と診断 された。

生活歴, 家族歴：特記すべき事項なし．

現症：来医時意識清明. 身長 $140 \mathrm{~cm}$, 体重 $50 \mathrm{~kg}$. 体 温 37.4 度. 血圧 $100 / 60$. 脈拍 90 回/分整. 腹部全体に著

2006年 2 月 24 日受付 2006 年 6 月15日採用

〈所属施設住所〉

干053-8567 苫小牧市本幸町 $1-2-21$
明な圧痛を認めた，腸蠕動音は聴取されない，腹膜刺 激症状を認め, 笳性防御, 反跳疼痛も明瞭。汎発性腹 膜炎の状態てあった。

入院時検查所見 (表 1 ): 白血球が3,200/ $\mu 1$ と減 少. $\mathrm{Hb} 10.6 \mathrm{~g} / \mu \mathrm{l}$ と貧血所見. LDH 325IU/1, AMY 593 IU/l, CK 304IU/l, CRP $19.5 \mathrm{mg} / \mathrm{dl}, \mathrm{BUN} 38 \mathrm{mg} / \mathrm{dl}$, Cre $1.3 \mathrm{mg} / \mathrm{dl}$ と上昇を認めた. また血液ガス分析では 代謝性アシドーシスの所見を認めた。

腹部単純 $X$ 線所見（図 1 ）：腸管内ガスの增加を認 め, free air が認められる. 矢印の部位に樹枝状のガス 像を認める。

腹部 CT 所見（図 2,3$):$ 空腸から下行結腸まで の広範囲にわたる腸管の腫大を認める. 少量の腹水も 認め, free air も認められる. 全肝にわたって門脈内 に，抹消に達する樹枝状に広がる air density を認め る.ガス像は門脈本管にも認められ，さらに上腸間膜 静脈内にも確認される.上腸間膜動脈内は動脈硬化に よると思われる石灰化の所見を認めるが，明らかな血 栓の存在は同定されない.

以上上り, 身体所見, 臨床症状, 血液検查, 画像所 見から判断して、腸管壊死を伴った腸管穿孔による汎 発性腹膜炎の診断て同日緊急手術を施行した。

手術所見（図 4)：暗血性の污染腹水を多量に認め, Treitz 鞄帯近傍の空腸から結腸脾彎曲まで，広範囲に 
表 1 入院時検查所見

\begin{tabular}{|c|c|c|c|c|c|c|c|c|}
\hline WBC & $\quad 3,200$ & $/ \mu 1$ & $\mathrm{TP}$ & 6.0 & $\mathrm{~g} / \mathrm{dl}$ & APTT & 43.9 & sec \\
\hline $\mathrm{RBC}$ & $358 \times 10^{4}$ & $/ \mu 1$ & Alb & 3.6 & $\mathrm{~g} / \mathrm{dl}$ & PT time & 16.2 & sec \\
\hline $\mathrm{Hb}$ & 10.6 & $g / \mu 1$ & $\mathrm{~T}-\mathrm{Bil}$ & 1.6 & $\mathrm{mg} / \mathrm{dl}$ & PT \% & 65 & $\%$ \\
\hline HCT & 31.4 & $\%$ & AST & 28 & $\mathrm{IU} / 1$ & PT-INR & 1.38 & \\
\hline \multirow[t]{2}{*}{ Plt } & $14.4 \times 10^{4}$ & $/ \mu 1$ & ALT & 13 & $\mathrm{IU} / 1$ & Fib & 527 & $\mathrm{mg} / \mathrm{dl}$ \\
\hline & & & LDH & 325 & $\mathrm{IU} / 1$ & FDP & 22.6 & $\mu \mathrm{g} / \mathrm{ml}$ \\
\hline BUN & 38 & $\mathrm{mg} / \mathrm{dl}$ & ALP & 137 & $\mathrm{IU} / 1$ & & & \\
\hline \multirow[t]{2}{*}{ Cre } & 1.3 & $\mathrm{mg} / \mathrm{dl}$ & $\gamma$-GTP & 7 & $\mathrm{IU} / 1$ & $\mathrm{PH}$ & 7.247 & \\
\hline & & & $\mathrm{AMY}$ & 593 & $\mathrm{IU} / \mathrm{l}$ & $\mathrm{pO} 2$ & 70.1 & $\mathrm{mmHg}$ \\
\hline $\mathrm{Na}$ & 131 & $\mathrm{mEq} / \mathrm{dl}$ & $\mathrm{CK}$ & 304 & $\mathrm{IU} / 1$ & $\mathrm{pCO} 2$ & 33.8 & $\mathrm{mmHg}$ \\
\hline $\mathrm{K}$ & 5.0 & $\mathrm{mEq} / \mathrm{dl}$ & CRP & 19.5 & $\mathrm{mg} / \mathrm{dl}$ & $\mathrm{BE}$ & -8.6 & $\mathrm{mmol} / \mathrm{l}$ \\
\hline $\mathrm{Cl}$ & 95 & $\mathrm{mEq} / \mathrm{dl}$ & & & & & & \\
\hline $\mathrm{Ca}$ & 9.3 & $\mathrm{mEq} / \mathrm{dl}$ & & & & & & \\
\hline
\end{tabular}

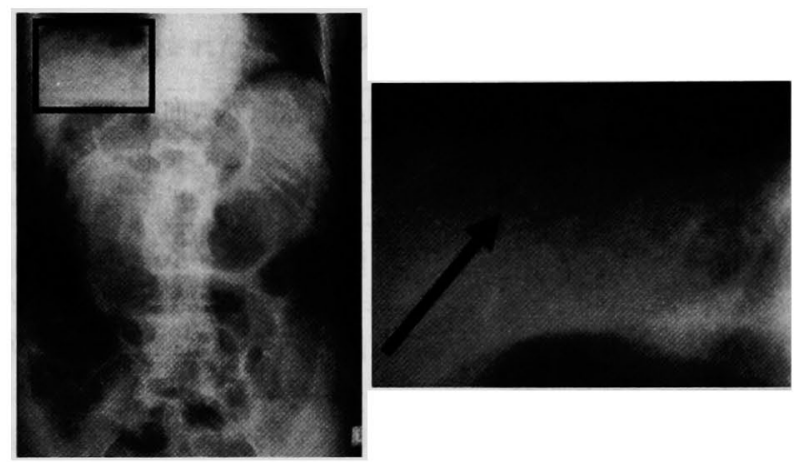

図 1 腹部 X 線写真：矢印の部位に樹枝状のガス像を認める.

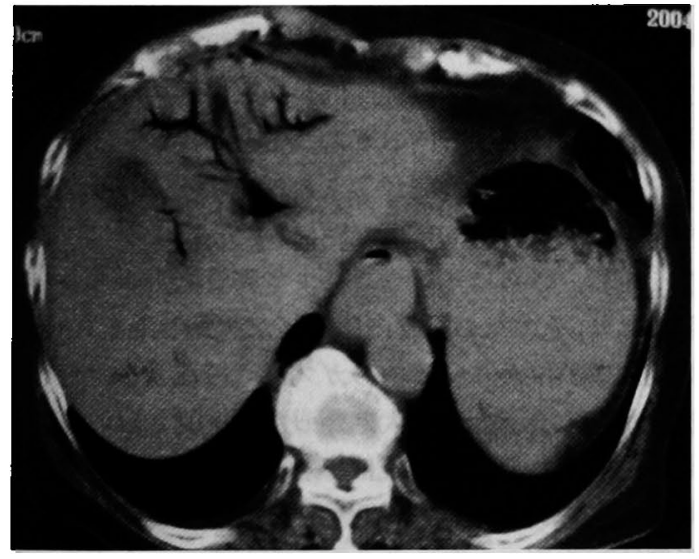

図 2 腹部 CT 所見：門脈内に樹枝状に広がる air density を認める。

渡って黒色から暗赤色に変色し腸管壊死の状態であっ た．小腸に穿孔も認められた，上腸間膜動脈は中枢側 から拍動を触知しなかった. 腸間膜内の静脈内に多数
の小さい気泡を確認した。これより腸管壊死をきたし た門脈内ガス血症を伴う上腸間膜動脈閉塞症と判断し た. 発症から少なくとも53時間は経過し，腸管の損傷 は高度で, 非可逆的損傷をきたしており，温存の適応 はない判断し，大量腸管切除術（小腸垔全切除術，拡 大結腸右半切除術，空腸㿉造設術）を施行した。

摘出標本の病理組織所見（図 5 )：肉眼所見では, Treitz 鞄帯から結腸脾彎曲までの広範圈の腸管壊死 を認めた。病理組織所見では，腸間膜内の太い動脈は 高度の動脈硬化像を認め，内腔はほほ閉塞していた。 小腸粘膜上皮は虚血による高度の変性を認め，粘膜下 には高度の浮腫, 腸管拡張を認めた。結腸粘膜にも同 様に虚血性変化を認め, 粘膜下組織内には高度の浮腫 を伴っていた，小腸粘膜下組織内の出血内に，ガス空 胞様の部位を認め, 異物巨細胞の被覆は明らかではな いため確定できないが, 腸葆胞性気腫症 (pneumatosis cystoides intestinalis) が疑われる所見を羿めた。

術後経過：術後 3 日で集中治療室から一般病棟に転 


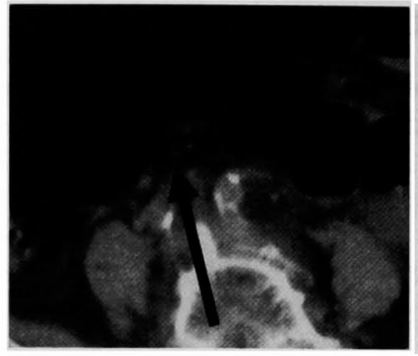

A

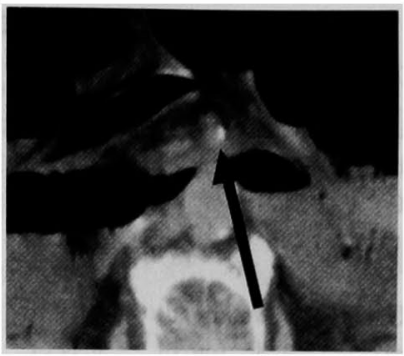

B

图 3 腹部 CT 所見 $\mathrm{A}$ ：ガス像は門脈本管にも認められ，さらに 上腸間膜静脈内にも確認される。 B : 上腸間膜動脈内は動脈硬化 によると思われる石灰化の所見を認めるが, 明らかな血栓の存在 は同定されない.

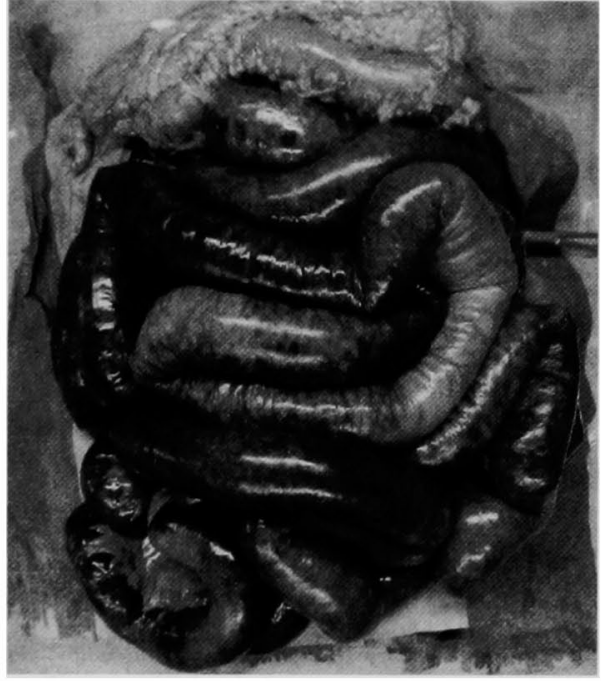

図 4 術中所見：暗血性の污染腹水を多量に認 め, Treitz 鞄帯近傍の空腸から結腸脾彎曲まで の広範囲に渡る腸管壊死の状態であった。

棟した. DIC, 敗血症の発症なく, 良好に経過した. 肝 機能も術後 5 日目をピークに徐々に改善した. 術後の 短腸症候群は, 腸蠕動方進期も比較的安定した経過を たどり，人工肛門からは一日量で $400-500 \mathrm{ml}$ の水溶性 の下痢を認めるのみであった，血液検査で栄養指標を 確認しつつ，まずは total parental nutrition の方針と し，静脈内リザーバーを挿入した，術後20日で他院に 軽快転院した。術後16力月が経過した現在, 半消化栄 養剤を併用しつつ中心静脈栄養にて経過観察中であ る.

\section{考察}

門脈内ガス血症は1955年に小児の壊死性腸炎に合併 したものとして初めて報告"されれて降，数多く報告 されている。患者背景は様々で, 上腸間膜動脈閉塞症， 絞扼性イレウス，壊死性腸炎，胃潰瘍，急性膵炎，ク ローン病, 肝移植後といつた病態から, 注腸造影検查, 大腸内視鏡検査といった検查手技に伴う例も報告2/31 されている.門脈ガスの発生機序は，原因が多㞳に渡 っていることから現在のところ，一元的には説明され ない. Liebmanによる1978年の報告 ${ }^{4}$ や，実験的検討 ${ }^{5}$ などから総合すると，腸管の壊死，潰瘍，腹部外傷と いった腸管粘膜の損傷を背景として，そこにイレウス や，検查に伴うガス注入などによる腸管内圧の上昇が 加わると，(1)粘膜の破綻部位から直接がスが流入する という説と，(2)腸管内のガス産生菌が侵入し局所でが スを産生するという説が考えられている.本症例では, 粘膜が病理組織学的に広範囲にわたって虚血による変 性を呈し，さらにイレウスによる腸管拡張が非常に高 度であり，そのため腸管内圧が高かったと考えられる。 粘膜損傷部位から腸管内のガスが直接流入したという 機序が発生要素として大きかったと推測される.

門脈内ガス血症の予後は一般に不良とされる。1978 年の報告4では死亡率は75\%であった。これは70\%が 腸管壊死症例であり，その死亡率が高かったことに起 因する.しかし，その後の CT, US といった画像診断 装置の発達に伴い，非常に小さな門脈内ガスも検出可 能になるにつれて，良性疾患や検査に伴う報告も増加 した．その結果，門脈ガス血症を認めた症例全体の死 亡率は1995年の報告6)では57\%に，2003年の報告7)では $34.6 \%$ ある。吃，門脈内ガス血症を呈しているこ 


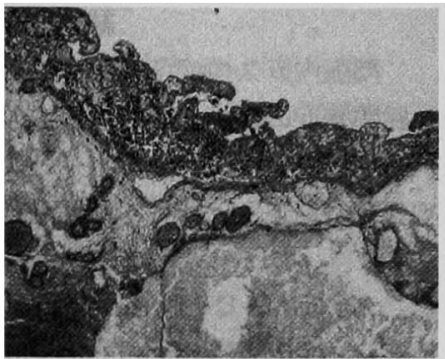

A

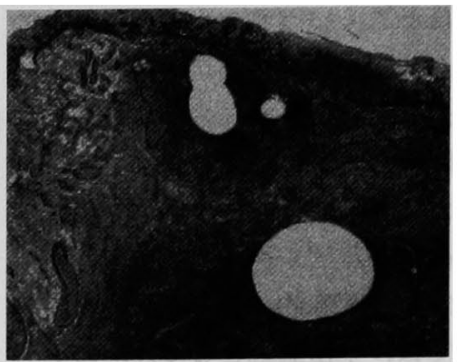

B

図 5 摘出標本の) 病理組織所見 (空腸, Hematoxylin eosin stain, A : $\times$ $100 \mathrm{~B}: \times 40):$ 小腸粘膜上皮は虚血による高度の変性を認め, 粘膜下 には高度の浮腫, 脈管拡張を認める. 小腸粘膜下組織内に, ガス空胞様 の部位を認める。

表 2 本邦で報告された門脈内ガス血症を伴う上腸間膜䌾脈閉塞症の救命例

\begin{tabular}{|c|c|c|c|c|c|c|}
\hline 著者 & 年 & 藏/性 & 合併症 & interval & 治癔 & 予後 \\
\hline 桑原 & 92 & $54 \mathrm{M}$ & 心房細動 弁膜症 小脳梗塞後 & 18時間 & $\begin{array}{l}\text { Treitz 勒帯加ら } 60 \mathrm{~cm} \text { より } 20 \mathrm{~cm} \text { 切除, } \\
145 \mathrm{~cm} \text { より上行結腸中央まて切除し端々吻合 }\end{array}$ & $\begin{array}{l}35 \text { POD } \\
\text { 退院 }\end{array}$ \\
\hline 中村 & 94 & $44 \mathrm{~F}$ & 胃全摘術後 & 10時間 & Y 脚吻合部肛門側 $40 \mathrm{~cm}$ 上り横行結腸中央を切除 & $\begin{array}{l}50 \text { POD } \\
\text { 退院 }\end{array}$ \\
\hline 三好 & 95 & $64 \mathrm{M}$ & Burger 病 弁膜症 & 13時間 & 墒死した回腸を $40 \mathrm{~cm}$ 切除 & $\begin{array}{l}29 \text { POD } \\
\text { 退院 }\end{array}$ \\
\hline 土廣 & 96 & $63 \mathrm{M}$ & 心房細動 僧帽弁置換術後 & 4 時間 & ワルファリンカリウム内服, ウロキナーゼの静脈内投与 & $\begin{array}{l}12 \text { POD } \\
\text { 退院 }\end{array}$ \\
\hline 土廣 & 96 & $68 \mathrm{~F}$ & 榶尿病 高血圧 高脂血症 腎炎 & 発症当日 & Treitz 靱帯から $150 \mathrm{~cm}$ より回盲部まで切除 & $\begin{array}{l}44 \text { POD } \\
\text { 退院 }\end{array}$ \\
\hline 营原 & 98 & $71 \mathrm{M}$ & 心房細動＼cjkstart慢性腎不全＼cjkstart脳梗塞後 & 32時間 & Treitz 靶带から $24 \mathrm{~cm}$ より横行結腸まで切除 & $\begin{array}{l}212 \text { POD } \\
\text { 退院 }\end{array}$ \\
\hline 塚田 & 03 & $72 \mathrm{M}$ & $\begin{array}{c}\text { 閉塞性動脈硬化症 心房細動 } \\
\text { 僈性閉塞性肺疾患 }\end{array}$ & 53時間 & Treitz 靬帯から50cm より胿弯曲まで切除 & $\begin{array}{l}43 \text { POD } \\
\text { 他病死 }\end{array}$ \\
\hline 黒木 & 04 & $58 \mathrm{M}$ & 塔尿病＼cjkstart慢性督不全(人工透析) & 18時間 & Treitz 靶帯から $80 \mathrm{~cm}$ より 回盲部まで切除 & $\begin{array}{l}93 \text { POD } \\
\text { 退院 }\end{array}$ \\
\hline 自験 & 04 & $85 \mathrm{~F}$ & 譄梗塞後 & 53時間 & Treitz 鞄带から $20 \mathrm{~cm}$ より脾弯曲まで切除 & $\begin{array}{l}20 \mathrm{POD} \\
\text { 退院 }\end{array}$ \\
\hline
\end{tabular}

と自体は必ずしも予後不良であることを示唆しない. 一方で上腸間膜動脈閉塞症は，急性腹症の $1 \%$ 以下 の発症率であるが, 死亡率は $50 \%$ 程度との報告 ${ }^{8)-11) か ゙ ~}$ 多い.さらに門脈内ガス血症を併発する上腸間膜動脈 閉塞症, 腸管虚血の報告を検討すると, 門脈内ガス血 症を呈する症例のうち, それら疾患が原因であったも のは全体の27\%であったが, 死亡率は $71.4 \%$ と高率で， しかも生存例は手術を施行した症例のみであったとの 報告》や，本邦での51例を検討した1998年の報告 ${ }^{12)}$

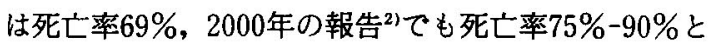

いずれも高率である。これより，閒脈内ガス血症を併 発する上腸間膜動脈閉塞症はより重篤であるといえ る.

上腸間膜動脈閉塞症は, その病態から早期診断, 治 療が重要である. 画像検査に関しては, 腹部超音波検 查や，造影 CTで血管閉塞が証明されれば確定診断は 可能である. また診断後の治療にも継続できる血管造 影検査は, 最も有力な検査法であるとされ, 発症から 10時間以内の緊急診断および, ウ口キナーゼによる選

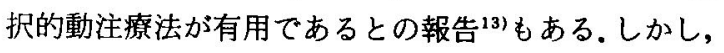


必ずしも簡便な方法ではなく，いつでも施行可能な施 設も限られている現状がある，いずれにせよ，発症か ら治療開始までの時間が長ければ長いほど予後は不良 となり, 発症から15時間以上経過している症例では不 可逆的な腸管壊死をきたしている可能性が高い. 手術 開始まで48時間が救命のゴールデンタイムであるとの 報告 ${ }^{11} も$ ある.いずれにせよ，基本的に本疾患を疑い腹 膜炎を呈している症例では, 手術適応となり, その夕 イミングを逸してはならない。

本症例のように筋性防御, 腹水貯留, 腸蠕動音の消 失など汎発性腹膜炎が考えられる場合は腸管壊死を疑 い緊急手術の適応となる。

本邦で報告された門脈内ガス血症を伴う上腸間膜動 脈閉塞症の 8 救命例(5)12)14) -18)を示す (表 2 ). 上記のよ うに門脈内ガス血症を伴う上腸間膜動脈閉塞症の予後 は不良である。しかし，発症初期に診断しえた症例は 血栓溶解療法により, 保存的に軽快しえた症例14)や, 本 症例のように発症から長時間経過した症例でも壊死腸 管の切除により救命しえた報告 ${ }^{15)}$ もる，発症早期の 症例でも門脈内ガス血症を認める症例や，腸管の壊死 範囲に関しても, 回腸 $30 \mathrm{~cm}$ だけが壊死していた症例 も含まれ, 門脈内ガス血症が, 発症からの長時間経過 や,広範囲の腸管壊死を必ずしも意味しないといえる。

本症例の予後が良好であった原因としては, 第 1 に 術前の血行動態が安定しており，また大きな合併症が なかったこと. 第 2 に小腸穿孔をきたしていたが, 腹 腔内の污染はある程度限局されており, 結腸の穿孔は なかったこと. 第 3 に周術期に敗血症を発症しなかっ たこと，などの可能性が考えられる。

門脈内ガス血症は, その発症機序から判断して, シ ヨックを呈している患者では, 腸管内のガス産生菌に よる敗血症徵候の一つである可能性がある ${ }^{16)}$. しかも 腸管壊死を伴っている場合は手術しか救命手段はな い.また，上記のように門脈内ガス血症を呈している こと自体は必ずしも予後不良であることを示唆しな い.したがって，門脈内ガス血症を認めた場合，それ が明らかに検查手技などによるもので，かつ腹部所見 を䜅めない症例以外は, 消化管の粘膜損傷, 敗血症の 徵候である可能性がある。そしてその背景には上腸間 膜動脈閉塞症を含め, 手術を必要とする腸管壊死をも たらす疾患があるととらえ, 迅速な診断, 治療法の決 定が救命の鍵となる。

\section{結語}

門脈内ガス血症所を呈するも救命できた上腸間膜動 脈閉塞症の症例を経験した。同病態は死亡率が高いが, 本症例のように発症から長時間が経過しても救命でき る症例もあり, 積極的治療の必要があると思われた。

\section{文献}

1) Wolfe JN, Evens WA: Gas in the portal veins of the liver in infants. Am J Roentgenol $74: 486$ $-489,1955$

2) Carmen S, Sergi Q, Eloy E, et al : Portmesenteric vein gas: pathologic mechanism, CT find. ings, and prognosis. Radiographics $20: 1213-$ 1224, 2000

3）藤井恭子, 中村志郎, 原順一地：門脈ガス血症 を併発したクローン病の 1 例。日消誌 $100: 42-$ 47,2003

4) Liebman PR. Patten MT, Manny J, et al: Hepatic-portal venous gas in adults. Ann Surg $187: 281-287,1978$

5）山口敏郎：門脈内ガス血症の発生機序に関する実 験研究。日消外会誌 $13: 1260-1270,1980$

6) 三好和也，松井武志，雁木淳一他：門眽ガス血症 を伴った急性上腸間膜動脈閉塞症の 1 手術治験 例. 日消外会誌 $28: 77-81,1995$

7) David AL, Shea CG, William WM, et al : Portal venous gas detected by computed tomography : is surgery imperative? Dig Surg $20: 306-315$, 2003

8）小笠原敬三, 高三秀成：急性上腸間膜動脈閉塞症 の臨床的検討. Arch Jpn Chir 63:70-75, 1994

9）井口雅史, 西村元一, 三輪晃一他：急性上腸間膜 動脈閉塞症に対する診断・治療の問題点. 日腹部 救急医会誌 $19: 329-335,1999$

10）田中屋宏爾，小長英二，竹内仁司：急性上腸間膜 動脈閉塞症の検討 日外科系連会誌 $24: 576-$ 579, 1999

11）勝又健次, 山本啓一郎，草沢龍人他：急性上腸間 膜動脈閉塞症症例の検討 診断, 治療, 予後につ いて. 日腹部救急医会誌 $21: 695-701 ， 2001$

12）菅原俊道, 岡田伸之, 鈴木 克他: 門脈ガス血症 を伴った急性上腸間膜動脈閉塞症の 1 救命例. 日 消外会誌 $31: 955-959,1998$

13）近森文夫, 福田禎治, 仁藤 学地：急性上腸間膜 動脈閉塞症の臨床的検討. 日臨外会誌 $53: 43-$ 
48, 1992

14）土廣典之, 佐々木克哉，松山和男他：門脈ガス血 症を発症早期に診断した 2 救命例. 日腹部救急医 会誌 $16: 1345-1348,1996$

15）塚田登思美, 大高雅彦, 赤羽貿浩他：門脈ガス血 症をともなった上腸間膜動脈血栓症の 1 例. 日消 誌 $100: 313-316,2003$

16）中村達也, 村尾佳則, 西村 章他: 肝門脈内ガス 血症を呈した広範团腸管壊死の 2 例一自験例およ
び本邦報告45例の検討一。日臨外会誌 $55: 2859$ $-2864,1994$

17）原義之, 片岡 誠, 佐藤篤司他：門脈内ガス血 症を伴った急性上腸間膜動脈閉塞症の 1 救命例. 日消外会誌 $25 ： 3007-3011 ， 1992$

18）黑木度和, 伊藤哲也, 伊藤周二他 : 維持透析患者 に発症した門脈ガス血症を伴う急性上腸間膜動脈 閉塞症の 1 救命例. 日透析医学会誌 $37: 1323$ 1326, 2004

\title{
A CASE OF SURVIVING ACUTE SUPERIOR MESENTERIC ARTERY OCCLUSION WITH HEPATIC PORTAL VENOUS GAS
}

\author{
Masaaki WATANABE, Syuusaku TAKAHASHI, Kunihiro HIROSE and Yutaka SAJI \\ Department of Surgery, Tomakomai City General Hospital
}

We report a case surviving acute superior mesenteric artery occlusion with hepatic portal venous gas, which has a grave prognosis Only 9 survivors including this case have been reported in Japan. An85-year-old woman with a past history of brain infarction complained of severe abdominal pain. Abdominal X-ray revealed a severe ileus image. Plain abdominal CT performed the next day showed hepatic portal venous gas. The physical examination indicated severe peritonitis. An emergency operation laparotomy, performed about 53 hours after onset, revealed severe necrosis of the small intestine from Treitz's ligament to the splenic flexure. All of the necrotic bowel was resected and a jejunostomy was performed. The length of the residual jejunum was about $20 \mathrm{~cm}$. Because of the length of the residual small intestine, a short bowel syndrome occurred. Other than that, the postoperative course was uneventful. The patient was discharged 20 days after the operation. 